\title{
Comparison of the cytotoxic effects of $\beta$-sitosterol oxides and a cholesterol oxide, $7 \beta$-hydroxycholesterol, in cultured mammalian cells
}

\author{
Lindsay Maguire ${ }^{1}$, Mikhail Konoplyannikov ${ }^{1}$, Alan Ford ${ }^{2}$, Anita R. Maguire $^{2}$ and \\ Nora M. O'Brien ${ }^{1 *}$ \\ ${ }^{1}$ Department of Food and Nutritional Sciences, University College, Cork, Republic of Ireland \\ ${ }^{2}$ Department of Chemistry, Analytical and Biological Chemistry Research Facility, University College, Cork, \\ Republic of Ireland
}

(Received 19 February 2003 - Revised 19 May 2003 - Accepted 10 June 2003)

\begin{abstract}
Phytosterols are plant sterols found in foods such as oils, nuts and vegetables. Phytosterols, in the same way as cholesterol, contain a double bond and are susceptible to oxidation. The objective of the present study was to assess the potential toxic effects of $\beta$-sitosterol oxides on U937 cells. The effects of increasing concentrations $(0-120 \mu \mathrm{M})$ of $\beta$-sitosterol oxides on cellular cytotoxicity, apoptosis, antioxidant status and genotoxicity was assessed over 12,24 and $48 \mathrm{~h}$ exposure periods. Following $12 \mathrm{~h}$, the viability of cells treated with $120 \mu \mathrm{M}$ - $\beta$-sitosterol oxides was reduced to $51.7 \%$ relative to control. At 24 and $48 \mathrm{~h}$, both 60 and $120 \mu \mathrm{M}$ - $\beta$-sitosterol oxides caused a significant decrease in cell viability. For comparison, a decrease in viability of cells treated with a cholesterol oxide, $7 \beta$-hydroxycholesterol $(7 \beta-\mathrm{OH}, 30 \mu \mathrm{M})$, was evident at $24 \mathrm{~h}$. An increase in apoptotic cells, assessed using Hoechst 33342 , indicates that the mode of cell death in U937 cells following exposure to $7 \beta-\mathrm{OH}(30 \mu \mathrm{M})$ and $\beta$-sitosterol oxides $(60$ and $120 \mu \mathrm{M})$ was by apoptosis. The increase in apoptotic cells after $12 \mathrm{~h}$ following treatment with $120 \mu \mathrm{M}$ - $\beta$-sitosterol oxides was accompanied by a decrease in cellular glutathione. Similarly, $7 \beta-\mathrm{OH}(30 \mu \mathrm{M})$ treatment resulted in decreased glutathione at $12 \mathrm{~h}$. Catalase activity was not affected by any of the treatments. $\beta$-Sitosterol oxides had no genotoxic effects on U937 and V79 cells as assessed by the comet and sister chromatid exchange assays respectively. In general, the results indicate that thermally oxidised derivatives of $\beta$-sitosterol demonstrate similar biological effects as $7 \beta-\mathrm{OH}$ in U937 cells, but at higher concentrations.
\end{abstract}

Phytosterol oxides: Cholesterol oxides: Cytotoxicity: Apoptosis

Phytosterols are found in plant foods and are structurally similar and functionally analogous to cholesterol in vertebrate animals. Recently, there has been increasing interest in the use of phytosterols as cholesterol-lowering agents. Esters of phytosterols or phytostanols are being incorporated into a growing spectrum of functional foods, including margarine and salad dressings, in a number of countries (Moreau et al. 2002). Because phytosterols contain structures similar to cholesterol, investigators have questioned whether they are susceptible to oxidation in the same fashion as cholesterol. The mechanisms of formation of cholesterol oxidation products (COP) are well documented (Tai et al. 1999); however, research on the oxidation of phytosterols has not been as extensive. In addition, the toxicity of COP and their potential harmful role in the development of atherosclerosis is acknowledged (Leonarduzzi et al. 2002) while the biological effects of phytosterol oxidation products (phytosterol oxides) are not well known and data in this field remain scarce.
The potential for formation of phytosterol oxides in plant foods has been noted (Dutta, 1999). Dutta \& Appelqvist (1997) reported that the phytosterol oxide content in vegetable oils increased after $2 \mathrm{~d}$ of frying. French fries fried in this vegetable oil also contained higher concentrations of phytosterol oxides than before frying. A commercial margarine enriched with phytosteryl esters was found to contain $0.1 \%$ of the phytosterols in the oxidised form (Grandgirard, 2002). As the authors of this report point out, a recommended daily intake of $2-4 \mathrm{~g}$ phytosterols could allow the ingestion of $2-4 \mathrm{mg}$ phytosterol oxides. This quantity is similar to the quantities of COP $(3-4 \mathrm{mg})$ that were analysed in the daily diets in the Netherlands and New Zealand (Van de Bovenkamp et al. 1988; Lake \& Scholes, 1997). Limited evidence suggests that food phytosterol oxides are absorbed in vivo (Grandgirard et al. 1999). Furthermore, the metabolism of phytosterols in vivo is not well understood particularly when high doses are ingested. Their in vivo transformation into phytosterol oxides cannot be 
excluded. Plat et al. (2001) reported that phytosterol oxides were present in elevated concentrations in serum from phytosterolaemic patients. Phytosterolaemia is a rare inherited sterol-storage disease characterised by very high concentrations of serum plant sterol.

Only a few studies have measured the biological effects of phytosterol oxides. Adcox et al. (2001) demonstrated that phytosterol oxides cause cellular damage in cultured macrophage-derived cells. Similar damage occurred due to COP, but the effect of phytosterol oxides was less severe. Kakis et al. (1977) reported that 7-ketocholesterol inhibited cholesterogenesis by 20-30\%, whereas 7-ketositosterol had no effect. Recent trends towards the replacement of animal oils with vegetable oils in the fast-food industry and the continued appearance of foods enriched with large amounts of phytosterols that are known to be liable to oxidation, together with the lack of information on the potency of phytosterol oxides, indicates a need for wider research in this area.

The available data suggest that the effects of phytosterol oxides in foods are qualitatively and quantitatively similar to those of COP. In cell culture, COP have been shown to be toxic to a variety of human and animal cell types, including smooth muscle cells, fibroblasts, vascular endothelial cells, macrophages and lymphocytes (Christ et al. 1993; Aupeix et al. 1995; Lizard et al. 1999; Lyons et al. 2001; O'Callaghan et al. 2001). It is not known whether COP exert the same effects in vivo, but damage to these cell types would assist in the development of atherosclerosis. In a number of these studies the mechanism of COP-induced toxicity was identified as apoptosis. Many factors that induce apoptosis have also been shown to elicit an oxidative stress (Ghibelli et al. 1999), so it may be that oxidative stress is central to the COP-induced apoptotic process. It has been previously reported that $7 \beta$-hydroxycholesterol $(7 \beta-\mathrm{OH})$-induced apoptosis in U937 cells was accompanied by changes in glutathione concentration and superoxide dismutase activity (O'Callaghan et al. 2002).

The most abundant phytosterol in nature is $\beta$-sitosterol (Fig. 1; Clifton, 2002). The main objective of the present study was to assess the effects of $\beta$-sitosterol oxides, produced as a result of heating the plant sterol, on the cytotoxicity, apoptosis and antioxidant status of U937 cells. The effects were compared with those of the cholesterol oxide, $7 \beta-\mathrm{OH}$. Changes in several cell parameters were measured including cell viability, morphological analysis of cell nuclei, DNA fragmentation, determination of

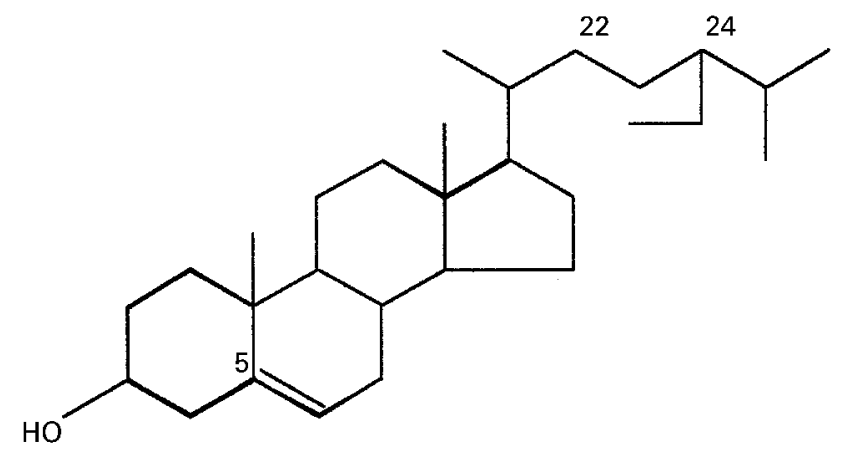

Fig. 1. The chemical structure of $\beta$-sitosterol. cellular glutathione levels and catalase activity. U937 cells are from a human monocytic blood cell line and are regularly employed as a macrophage reference model in studies investigating the cytotoxicity of COP. A second objective of the present study was to assess the potential genotoxicity of $\beta$-sitosterol oxides using the sister chromatid exchange (SCE) and alkaline comet assay (alkaline single-cell gel electrophoresis assay). Chinese hamster lung V79 cells were employed to measure SCE as these cells have long been utilised in cytogenetic studies (Perry \& Wolff, 1974; O'Leary et al. 2001). The aim was to determine whether $\beta$-sitosterol oxides were capable of modulating the levels of baseline DNA damage in these cells.

\section{Materials and methods}

\section{Chemicals and reagents}

All chemicals and cell culture reagents were obtained from the Sigma Chemical Co. (Poole, Dorset, UK) unless otherwise stated. Tissue culture plastics were supplied by Costar (Cambridge, UK). Cell lines were obtained from the European Collection of Animal Cell Cultures (Salisbury, Wilts, UK).

\section{Maintenance of cell lines}

Human monocytic U937 cells were grown in suspension in RPMI-1640 medium supplemented with $2 \mathrm{mM}$-L-glutamine and $10 \%(\mathrm{v} / \mathrm{v})$ fetal calf serum (FCS). Chinese hamster lung V79-4 fibroblast cells were maintained in Dulbecco's modified Eagle's medium supplemented with $10 \%$ (v/v) FCS and $2 \mathrm{mM}-\mathrm{L}-$ glutamine. The cells were grown at $37^{\circ} \mathrm{C}$ and $5 \%(\mathrm{v} / \mathrm{v}) \mathrm{CO}_{2}$ in a humidified incubator. All cell lines were screened for mycoplasma contamination by the Hoechst staining method (Mowles, 1990) and were cultured in the absence of antibiotics. Exponentially growing cells were used throughout.

\section{Production of $\beta$-sitosterol oxides}

Individual phytosterol oxidation products are not commercially available. Therefore, these were prepared: (i) oxidation products of $\beta$-sitosterol ( $\beta$-sitosterol oxides) by heat treatment; (ii) the $\alpha$ - and $\beta$-epoxide (sitosterol$5 \alpha, 6 \alpha$-epoxide and sitosterol-5 $5,6 \beta$-epoxide) in a $5: 1$ ratio by oxidation of $\beta$-sitosterol. Commercial $\beta$-sitosterol (>97\% $\beta$-sitosterol (by GC), residual campesterol and stigmasterol) was obtained from Sigma-Aldrich and oxidised without further purification. Oxidation of the sterol was carried out according to the procedure of Daly et al. (1983). Briefly, $\beta$-sitosterol $(10 \mathrm{~g})$ was heated at $100^{\circ} \mathrm{C}$ for $48 \mathrm{~h}$ in an open round-bottomed flask in a dark oven. The heat-treated sterols were dissolved in boiling absolute ethanol (reagent grade), concentrated under vacuum at room temperature and cooled to $4^{\circ} \mathrm{C}$ overnight. Crystals of unoxidised phytosterols were removed by filtration and the filtrate was further concentrated. The filtrate was analysed by TLC and NMR-spectroscopy. For TLC analysis, $50 \mathrm{mg}$ of the oxidised sterol was dissolved in $1 \mathrm{ml}$ redistilled diethyl ether (reagent grade). Of this solution, $50 \mu \mathrm{l}$ was applied as an individual spot to $200 \times 200 \mathrm{~mm}$ plastic 
sheets pre-coated with silica gel. Chromatographs were developed in diethyl ether, dried and sprayed with $50 \%$ (v/v) $\mathrm{H}_{2} \mathrm{SO}_{4}$ followed by heating for a few min at $100^{\circ} \mathrm{C}$ to char the separated oxidation products. The typical TLC plate revealed four or more products of oxidation (Fig. 2). This was confirmed by NMR analysis. The filtrate yielded approximately $2 \mathrm{~g}$ phytosterol oxides when dried overnight in a vacuum desiccator.

To prepare the $\alpha$ - and $\beta$-epoxides, $\beta$-sitosterol was oxidised according to a procedure described by Fieser \& Fieser (1967). $\beta$-Sitosterol (1.8 g) dissolved in methylene chloride $\left(\mathrm{CHCl}_{3}\right)$ was added to a solution of m-chloroperbenzoic acid in $\mathrm{CHCl}_{3}$ at $25^{\circ} \mathrm{C}$ and stirred for $2 \mathrm{~h}$. The reaction mixture was quenched with saturated sodium sulfite, stirred for an additional $5 \mathrm{~min}$, separated and the aqueous phase extracted with $\mathrm{CH}_{2} \mathrm{Cl}_{2}$. The combined organic phases were washed with saturated $\mathrm{NaHCO}_{3}$ and finally with saturated $\mathrm{NaCl}$ solution followed by drying over $\mathrm{MgSO}_{4}$. The solvent was removed under vacuum and the residue dried overnight yielding $1.62 \mathrm{~g}$ of products. The product obtained was analysed by TLC and NMR-spectroscopy. The typical TLC plate (Fig. 2) revealed one spot assigned probably to both $\alpha$ - and $\beta$-epoxide, while NMR-spectroscopy showed that the $\alpha$-epoxide ( $\alpha$-epoxysitosterol) was the prevailing product (data not shown).

\section{Treatment of cells with sterol oxides}

U937 cells were adjusted to a density of $1 \times 10^{5}$ cells $/ \mathrm{ml}$ and compounds were added in reduced serum media, $2.5 \%(\mathrm{v} / \mathrm{v})$ FCS. Cells were treated with $\beta$-sitosterol (30 and $60 \mu \mathrm{M})$, increasing concentrations of $\beta$-sitosterol oxides $(0-120 \mu \mathrm{M}), \alpha$-epoxysitosterol $(60 \mu \mathrm{M})$ or $7 \beta-\mathrm{OH}$

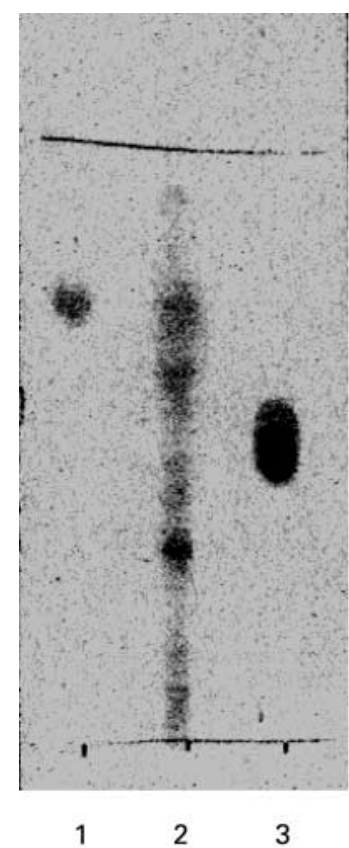

Fig. 2. Oxidation products of $\beta$-sitosterol observed on silica gel TLC plates developed in diethyl ether using vanilline. $1, \beta$-sitosterol; 2 , oxidation products of $\beta$-sitosterol after $48 \mathrm{~h}$ heating at $100^{\circ} \mathrm{C} ; 3$, sitosterol- $5 \alpha, 6 \alpha$-epoxide.
$(30 \mu \mathrm{M})$. All compounds were dissolved in ethanol for delivery to cells and the final concentration of ethanol in cultures did not exceed $0.5 \%$ (v/v). Equivalent quantities of ethanol were added to control cells and samples were incubated for 12,24 and $48 \mathrm{~h}$ at $37^{\circ} \mathrm{C}$ and $5 \%(\mathrm{v} / \mathrm{v}) \mathrm{CO}_{2}$.

\section{Cell viability}

The viability of the cells was assessed after 12, 24 and $48 \mathrm{~h}$ by the fluorochrome-mediated viability assay as described by Strauss (1991). Briefly, cells were mixed 1:1 (v/v) with a solution of fluorescein diacetate and ethidium bromide, then incubated at $37^{\circ} \mathrm{C}$ for $2-5 \mathrm{~min}$ before being layered onto a microscope (Micron Optical Co. Ltd., Wicklow, Republic of Ireland) slide. Under these conditions, live cells fluoresce green, whereas dead cells fluoresce red. Dying cells have a green cytoplasm and red nucleus. Samples were examined at $200 \times$ magnification on a Nikon fluorescence microscope (Micron Optical Co. Ltd, Wicklow, Republic of Ireland) using blue light (450$490 \mathrm{~nm}$ ). Cells (200) were scored from each slide and cell viability was expressed as the percentage of viable (green) cells relative to the control.

\section{Morphological analysis of cell nuclei}

Nuclear morphology of control and treated cells was assessed by fluorescence microscopy after staining with Hoechst 33342 . Approximately $4 \times 10^{5}$ cells were centrifuged at $200 \mathrm{~g}$ for $10 \mathrm{~min}$ to form a pellet. Hoechst 33342 stain $(200 \mu \mathrm{l}, 5 \mu \mathrm{g} / \mathrm{ml})$ was added and the samples incubated at $37^{\circ} \mathrm{C}$ and $5 \%(\mathrm{v} / \mathrm{v}) \mathrm{CO}_{2}$ for $1 \mathrm{~h}$. Stained samples were placed on a microscope slide and examined under u.v. light (Nikon Labophot fluorescence microscope, $400 \times$ magnification). A total of 300 cells per sample were analysed and the percentage of fragmented and condensed nuclei was calculated. Apoptotic cells were characterised by nuclear condensation of chromatin and/or nuclear fragmentation (Dubrez et al. 1996).

\section{DNA fragmentation assay}

Detection of small DNA fragments was conducted as described in O'Callaghan et al. (1999). Briefly $2 \times 10^{6}$ cells were harvested and the pellets were lysed, RNAse A $(0.25 \mathrm{mg} / \mathrm{ml})$ was added and the samples incubated at $50^{\circ} \mathrm{C}$ for $1 \mathrm{~h}$. The condensate was spun down and proteinase $\mathrm{K}(5 \mathrm{mg} / \mathrm{ml})$ added. The samples were incubated at $50^{\circ} \mathrm{C}$ for a further $1 \mathrm{~h}$ before being loaded into the wells of a $1.5 \%$ (w/v) agarose gel. A 100-1500 bp DNA standard (Promega) was used to assess DNA fragmentation. Electrophoresis was carried out in $1.5 \%(\mathrm{w} / \mathrm{v})$ agarose gels prepared in tri(hydroxymethyl)-aminomethane-borate-EDTA buffer at $0 \cdot 3 \mathrm{~V} / \mathrm{mm}$. DNA was visualised under u.v. light on a transilluminator $(312 \mathrm{~nm})$ after ethidium bromide staining and photographed using a digital camera (Kodak, Anachem Ltd, Dublin, Republic of Ireland).

\section{Determination of catalase activity}

Catalase activity was determined by the method of Baudhuin et al. (1964) with some modifications. Briefly, 
$4 \times 10^{6}$ cells were centrifuged at $200 \mathrm{~g}$ for $10 \mathrm{~min}$ and washed with PBS. The pellets were lysed with $500 \mu \mathrm{l}$ ice-cold phosphate-EDTA buffer $(0 \cdot 1 \mathrm{M}$-sodium phosphate, $0.005 \mathrm{M}$-EDTA, $\mathrm{pH}$ 8) containing $1 \%(\mathrm{w} / \mathrm{v})$ Triton-X-100. After sonication, samples were centrifuged at $15000 \mathrm{~g}$ for $15 \mathrm{~min}$. A portion $(10 \mu \mathrm{l})$ of the supernatant fraction from the cells was mixed on ice with $500 \mu l$ assay mixture (20 mM-tri(hydroxymethyl)-aminomethane- $\mathrm{HCl}$, $\mathrm{pH} 7$ containing bovine serum albumin $(1 \mathrm{~g} / \mathrm{l})$ and $2 \cdot 35 \mathrm{M}-\mathrm{H}_{2} \mathrm{O}_{2}$ ). After $1 \mathrm{~min}$ the reaction was stopped by the addition of $1 \mathrm{ml}$ of a titanium oxysulfate solution $(2 \cdot 25 \mathrm{~g} / \mathrm{l})$ in $1 \mathrm{M}-\mathrm{H}_{2} \mathrm{SO}_{4}$. All tubes reached room temperature and the absorbance was measured at $405 \mathrm{~nm}$. Catalase activity was determined, based on the amount of $\mathrm{H}_{2} \mathrm{O}_{2}$ remaining, from a standard curve. Catalase activity was expressed relative to the protein content. Protein content was determined by the bicinchoninic acid method (Smith et al. 1985).

\section{Determination of cellular glutathione levels}

The cellular level of glutathione was measured according to the method of Hissin \& Hilf (1976). Briefly, $4 \times 10^{6}$ cells were centrifuged at $200 \mathrm{~g}$ for $10 \mathrm{~min}$ and washed with PBS. The pellets were lysed with $500 \mu \mathrm{l}$ ice-cold phosphate-EDTA buffer (0.1 M-sodium phosphate, $0.005 \mathrm{M}$-EDTA, $\mathrm{pH}$ 8) containing $1 \%$ (w/v) Triton $\mathrm{X}-100$. After sonication, samples were centrifuged at $15000 \mathrm{~g}$ for $15 \mathrm{~min}$. The supernatant fraction $(100 \mu \mathrm{l})$ was diluted in $1.8 \mathrm{ml}$ phosphate-EDTA buffer and mixed with $100 \mathrm{ml} o$-phthaldaldehyde $(1 \mu \mathrm{g} / \mu \mathrm{l})$. Samples were incubated at $25^{\circ} \mathrm{C}$ for $15 \mathrm{~min}$ and the fluorescence was detected at $420 \mathrm{~nm}$ following activation at $360 \mathrm{~nm}$. The glutathione concentration of the samples was determined from a standard curve. Glutathione concentration was expressed relative to the protein content. Protein content was determined by the bicinchoninic acid method.

\section{Comet assay (single-cell gel electrophoresis assay)}

DNA single-strand breaks were assessed by the alkaline single-cell gel electrophoresis assay or alkaline comet assay as described by Woods et al. (1999). Briefly, a single cell suspension was prepared and embedded in $1 \%(\mathrm{w} / \mathrm{v})$ low-melting-point agarose on a microscope slide. The cells were lysed in a high-salt buffer $(2.5 \mathrm{M}$ $\mathrm{NaCl}, 10 \mathrm{~mm}$-tri(hydroxymethyl)-aminomethane, $100 \mathrm{~mm}$ EDTA, $1 \%(\mathrm{w} / \mathrm{v})$ sarcosine, $1 \%(\mathrm{v} / \mathrm{v})$ Triton X-100, $10 \%(\mathrm{v} / \mathrm{v})$ dimethyl sulfoxide, $\mathrm{pH} 11)$ for $1.5 \mathrm{~h}$ at $4^{\circ} \mathrm{C}$, then subjected to alkali treatment in an electrophoresis tank to allow DNA unwinding (for $40 \mathrm{~min}$ at $4^{\circ} \mathrm{C}$ ). Without changing the alkali solution, the slides were electrophoresed (20 V, $25 \mathrm{~min}, 300 \mathrm{~mA}$ ) before being neutralised and stained with ethidium bromide. A Komet analysis system 4.0 developed by Kinetic Imaging Ltd (Liverpool, UK) linked to a CCD camera was used to quantify the length of DNA migration and the percentage of migrated DNA. The program calculated the Olive tail moment of every comet, which is the generally accepted parameter for estimation of the level of single-strand DNA breaks
(Olive \& Banath, 1993). Randomly selected cells (fifty) were analysed per sample.

\section{Sister chromatid exchange assay}

V79-4 fibroblast cells were used for the SCE assay because they have a stable karyotype and a short cell cycle. The cells were plated in Dulbecco's modified Eagle's medium supplemented with $10 \%$ (v/v) FCS and 2 mM-L-glutamine in $100 \mathrm{~mm}$ Petri dishes. The cells were seeded at a density of $1.1 \times 10^{5}$ cells $/ \mathrm{ml}$ and all compounds were added in reduced serum medium, $2.5 \%(\mathrm{v} / \mathrm{v})$ FCS. Cells were incubated with $\beta$-sitosterol (30 and $60 \mu \mathrm{M})$, increasing concentrations of $\beta$-sitosterol oxides $(0-120 \mu \mathrm{M})$ or $7 \beta-\mathrm{OH}$ $(30 \mu \mathrm{M})$ for $24 \mathrm{~h}$ in the dark at $37^{\circ} \mathrm{C}$ in $5 \%(\mathrm{v} / \mathrm{v}) \mathrm{CO}_{2}$. After incubation, the cells were harvested by scraping and treated with $0.075 \mathrm{M}-\mathrm{KCl}$ for $10 \mathrm{~min}\left(37^{\circ} \mathrm{C}\right)$. The samples were then fixed three times in freshly prepared ice-cold Carnoy's fixative before being dropped onto methanolcleaned microscope slides. Differential staining of the sister chromatids was visualised using the fluorescence plus Giemsa method of Perry \& Wolff (1974). Approximately twenty-five metaphases per slide were analysed for SCE, which were expressed as the number of SCE per chromosome. The number of metaphase spreads in a total of 1000 nuclei was counted to give the mitotic index.

\section{Statistics}

All data points are the mean values and standard errors of the mean of at least three independent experiments. Where appropriate, data were analysed by one-way ANOVA followed by Dunnett's test.

\section{Results}

Effect of $\beta$-sitosterol, $\beta$-sitosterol oxides, $\alpha$-epoxysitosterol and $7 \beta$-hydroxycholesterol on cell viability

Viability of U937 cells was determined using the fluorescein diacetate-ethidium bromide method. At $12 \mathrm{~h}$, treatment of U937 cells with $120 \mu \mathrm{M}-\beta$-sitosterol oxides reduced cell viability to $51.7 \%$ relative to the control $(P<0 \cdot 01)$. All other compounds had no significant effect on cell viability at this time point (Fig. 3 (A)). After $24 \mathrm{~h}, 7 \beta-\mathrm{OH}$ at $30 \mu \mathrm{M}$ and $\beta$-sitosterol oxides at 60 and $120 \mu \mathrm{M}$ significantly $(P<0.01)$ reduced cell viability to 74,65 and $34 \%$ respectively, relative to control. All other compounds were not toxic (Fig. 3 (B)). Upon increasing the duration of exposure to $48 \mathrm{~h}$ these compounds reduced the cell viability even further (Fig. 3 (C)). At all time points tested, the parent compound $\beta$-sitosterol (30 and $60 \mu \mathrm{M}), \alpha$-epoxysitosterol $(60 \mu \mathrm{M})$ and the lower concentration of $\beta$-sitosterol oxides $(30 \mu \mathrm{M})$ were not toxic to U937 cells.

Effect of $\beta$-sitosterol, $\beta$-sitosterol oxides, $\alpha$-epoxysitosterol and $7 \beta$-hydroxycholesterol on induction of apoptosis

Condensed and fragmented nuclei were determined by morphological examination following staining with Hoechst 33342. Cells with nuclei that were condensed or fragmented 


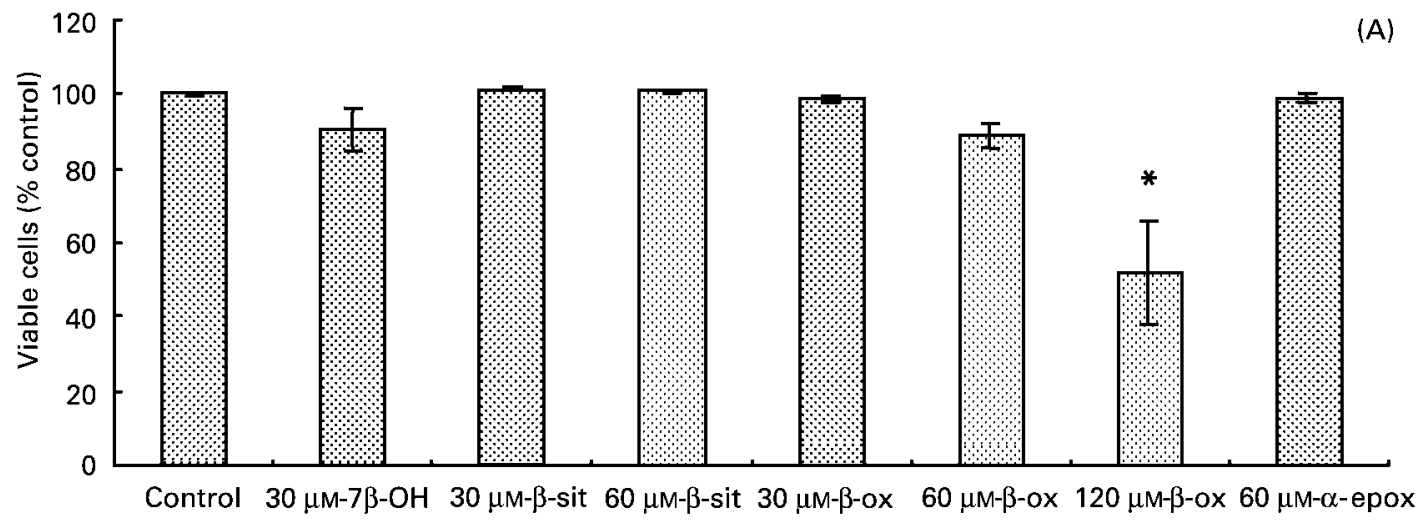

(B)
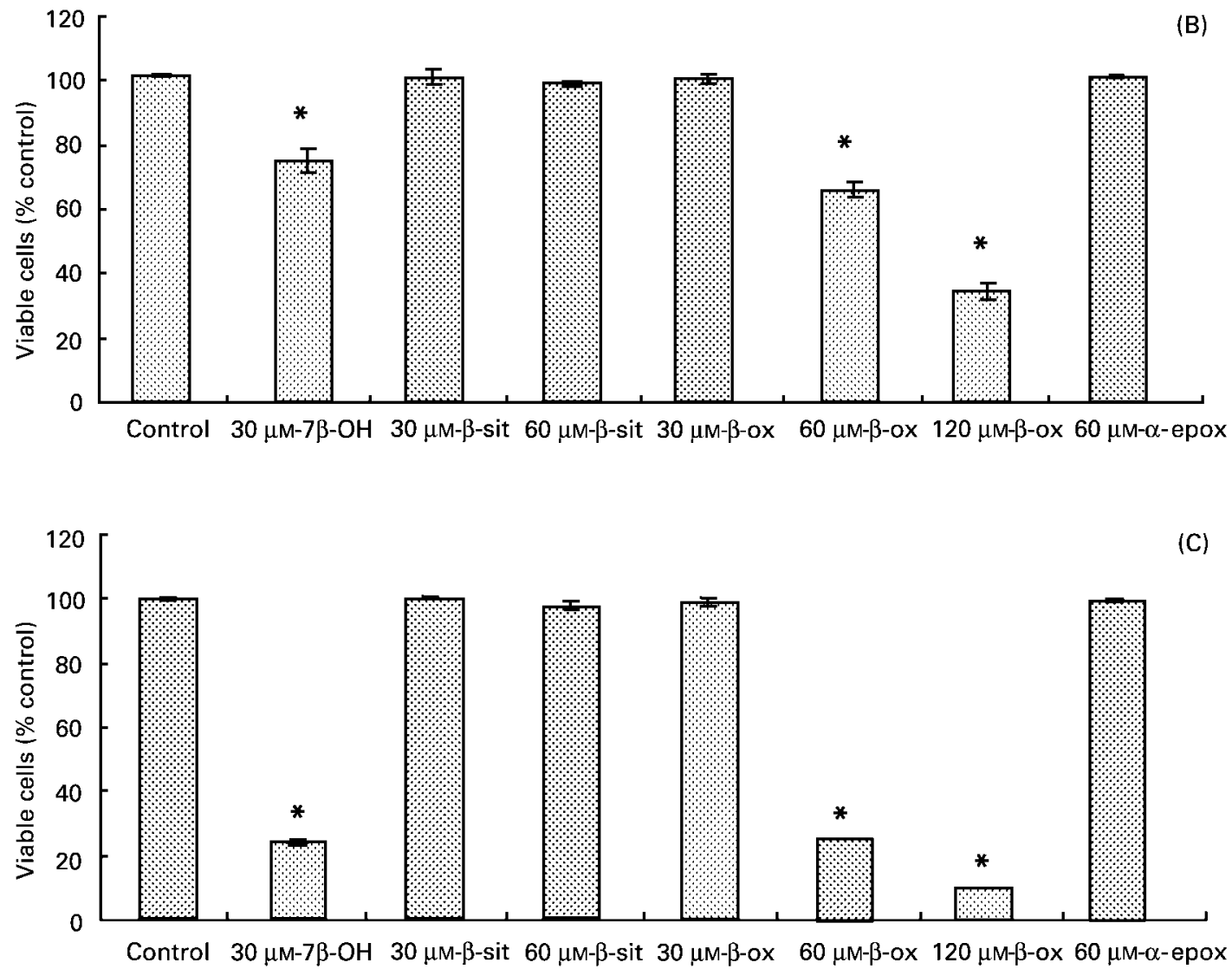

Fig. 3. The viability of U937 cells, expressed as a percentage of control, following a $12 \mathrm{~h}(\mathrm{~A}), 24 \mathrm{~h}(\mathrm{~B})$ and $48 \mathrm{~h}(\mathrm{C})$ incubation with $7 \beta$-hydroxycholesterol $(7 \beta-\mathrm{OH}), \beta$-sitosterol ( $\beta$-sit), $\beta$-sitosterol oxides ( $\beta$-ox) and sitosterol- $5 \alpha, 6 \alpha$-epoxide ( $\alpha$-epox). Viability was assessed by the fluorescein diacetate-ethidium bromide membrane permeability assay. Data are mean values for three independent experiments, with the standard errors of the mean represented by vertical bars. *Mean value was significantly different from control $(P<0.01$; ANOVA followed by Dunnett's test).

were identified as apoptotic. Following $12 \mathrm{~h}$, the percentage of apoptotic cells did not exceed $4 \%$ in the control cells. In contrast, there was a significant $(P<0 \cdot 01)$ increase in the percentage of apoptotic cells following exposure to 60 and $120 \mu \mathrm{M}-\beta$-sitosterol oxides. The percentage of apoptotic cells for all other samples was between $2-7 \%$ at this time point (Fig. 4 (A)). At the $24 \mathrm{~h}$ time point, the percentage of apoptotic cells did not exceed $6 \%$ in the control cells (Fig. 4 (B)). At this time, in addition to cells treated with 60 and $120 \mu \mathrm{M}-\beta$-sitosterol oxides, cells exposed to $30 \mu \mathrm{M}-7 \beta-\mathrm{OH}$ had significantly $(P<0 \cdot 01)$ increased apoptotic cell death. At $24 \mathrm{~h}$, cells treated with 60 and $120 \mu \mathrm{M}-\beta$-sitosterol oxides and $30 \mu \mathrm{M}-7 \beta-\mathrm{OH}$ produced a ladder-like pattern on agarose gels (Fig. 5). In contrast, DNA ladders were not seen in all the other treatment groups. At $48 \mathrm{~h}$, the percentage of apoptotic cells did not exceed $5 \%$ in the control cells (Fig. 4 (C)) but was significantly $(P<0.01)$ increased in cells exposed to $\beta$-sitosterol oxides $(60$ and $120 \mu \mathrm{M})$ and $7 \beta-\mathrm{OH}$. The order of potency for inducing apoptosis at 24 and $48 \mathrm{~h}$ was 


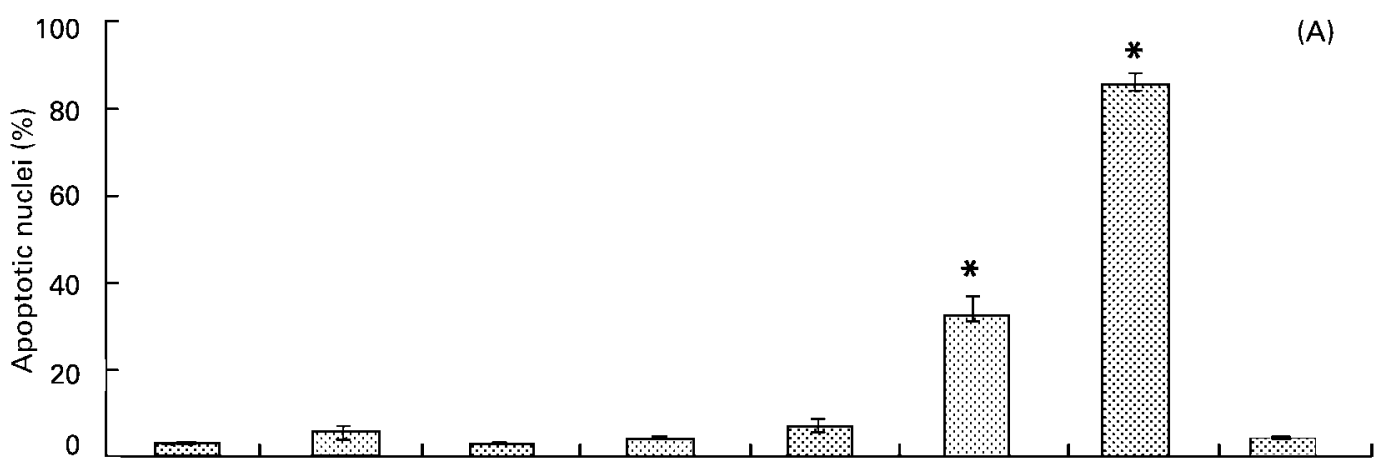

Control $30 \mu \mathrm{M}$-7 $\beta$-OH $30 \mu \mathrm{M}$ - $\beta$-sit $60 \mu \mathrm{M}$ - $\beta$-sit $30 \mu \mathrm{M}$ - $\beta$-ox $\quad 60 \mu \mathrm{M}$ - $\beta$-ox $120 \mu \mathrm{M}-\beta$-ox $60 \mu \mathrm{M}$ - $\alpha$-epox

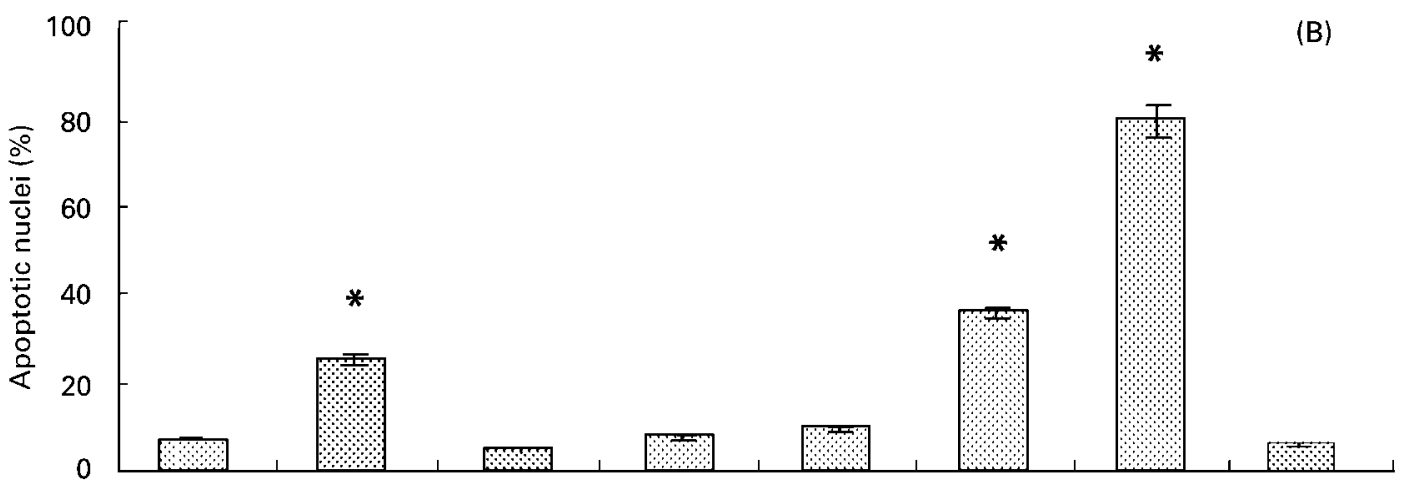

Control $30 \mu \mathrm{M}$-7 $\beta$-OH $30 \mu \mathrm{M}$ - $\beta$-sit $60 \mu \mathrm{M}$ - $\beta$-sit $30 \mu \mathrm{M}-\beta$-ox $60 \mu \mathrm{M}$ - $\beta$-ox $120 \mu \mathrm{M}$ - $\beta$-ox $60 \mu \mathrm{M}-\alpha$-epox

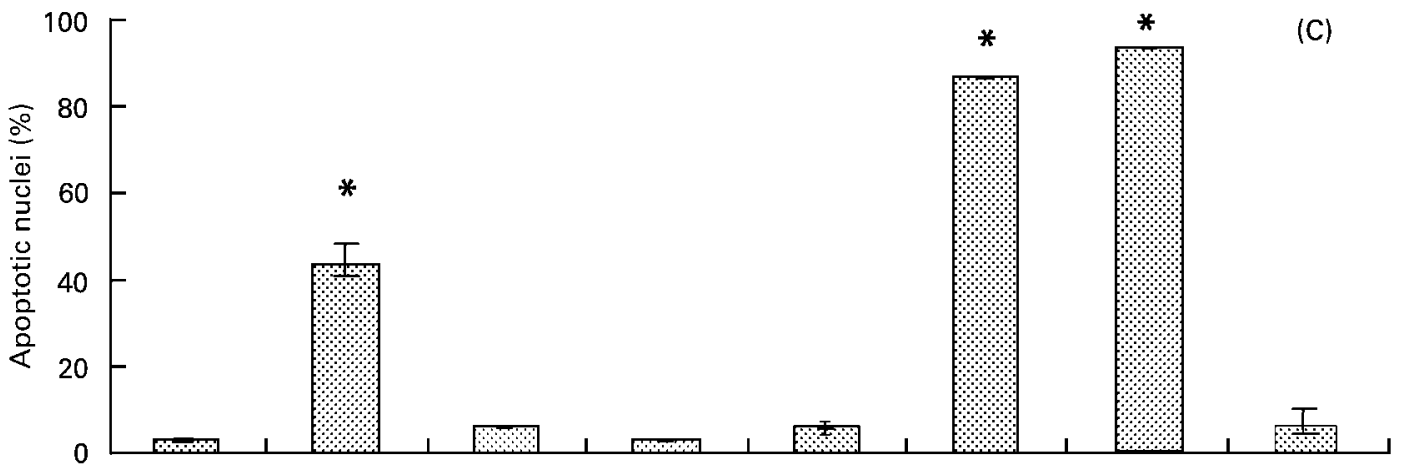

Control $30 \mu \mathrm{M}$-7 $\beta$-OH $\quad 30 \mu \mathrm{M}-\beta$-sit $60 \mu \mathrm{M}$ - $\beta$-sit $30 \mu \mathrm{M}-\beta$-ox $60 \mu \mathrm{M}$ - $\beta$-ox $120 \mu \mathrm{M}$ - $\beta$-ox $60 \mu \mathrm{M}-\alpha$-epox

Fig. 4. Condensed and fragmented nuclei, expressed as a percentage of control, following a $12 \mathrm{~h}(\mathrm{~A}), 24 \mathrm{~h}(\mathrm{~B})$ and $48 \mathrm{~h}(\mathrm{C})$ incubation with $7 \beta-$ hydroxycholesterol $(7 \beta-\mathrm{OH}), \beta$-sitosterol ( $\beta$-sit), $\beta$-sitosterol oxides ( $\beta$-ox) and sitosterol- $5 \alpha, 6 \alpha$-epoxide ( $\alpha$-epox). Condensed and fragmented nuclei were determined by staining with Hoechst 33342. Data are mean values for three independent experiments, with the standard errors of the mean represented by vertical bars. *Mean value was significantly different from control $(P<0.01$; ANOVA followed by Dunnett's test).

$120 \mu \mathrm{M}-\beta$-sitosterol oxides $>60 \mu \mathrm{M}-\beta$-sitosterol oxides $>30 \mu \mathrm{M}-7 \beta-\mathrm{OH}$.

Effect of $\beta$-sitosterol, $\beta$-sitosterol oxides, $\alpha$-epoxysitosterol and $7 \beta$-hydroxycholesterol on antioxidant status

To determine the antioxidant status of cells the cellular glutathione levels and catalase activity were measured. After $6 \mathrm{~h}$ none of the treated cells showed any significant change in the cellular glutathione levels. However, at the $12 \mathrm{~h}$ time point, cells treated with $120 \mu \mathrm{M}-\beta$-sitosterol oxides and $30 \mu \mathrm{M}-7 \beta-\mathrm{OH}$ showed a decrease in glutathione levels to approximately 46 and $73 \%$ relative to the control. At $12 \mathrm{~h}$ the glutathione concentration was 41.1 (SEM 3.7) $\mathrm{nmol} / \mathrm{mg}$ protein for the control and 18.9 (SEM 4.5) and 29.9 (SEM 3.2) $\mathrm{nmol} / \mathrm{mg}$ protein for the $\beta$-sitosterol oxides- and $7 \beta-\mathrm{OH}$-treated cells respectively. At the same time point $(12 \mathrm{~h})$, none of the treated cells showed any significant change in catalase activity. Catalase activity in control cells was 28.9 (SEM 0.4 ) units/mg protein, and in cells treated with $30 \mu \mathrm{M}-7 \beta-\mathrm{OH}, 60 \mu \mathrm{M}-$ and $120 \mu \mathrm{M}-$ $\beta$-sitosterol oxides, activity was 29.2 (SEM 0.4), 26.4 (SEM 2.3) and 23.8 (SEM 0.5) units/mg protein respectively. Results are from three independent experiments. 


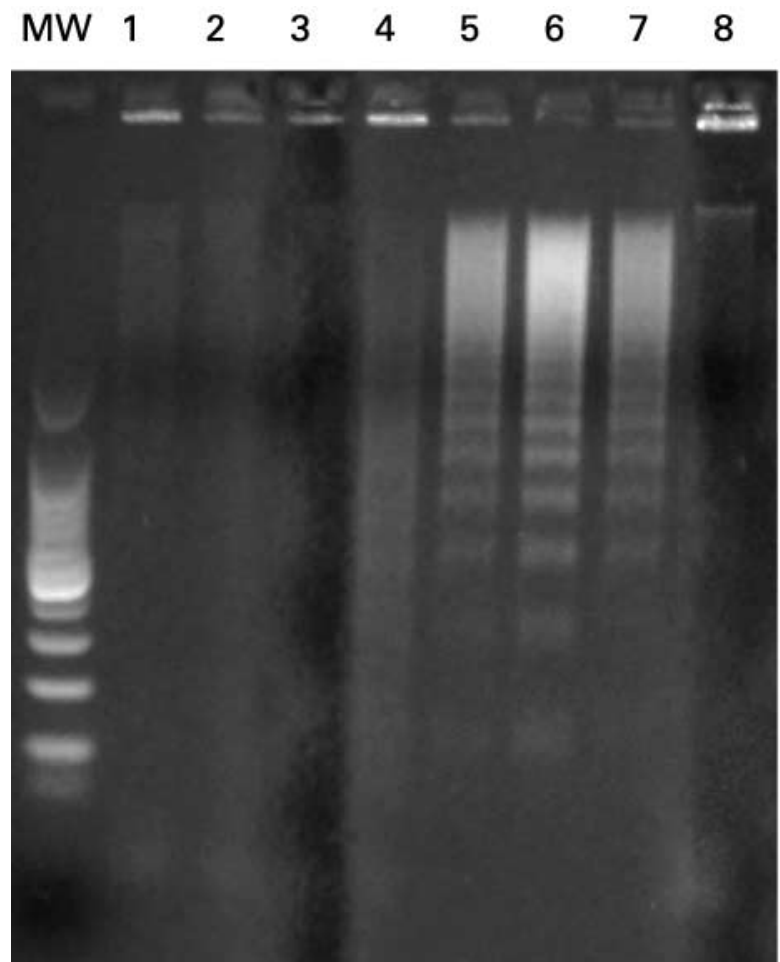

Fig. 5. Induction of DNA fragmentation following a $24 \mathrm{~h}$ incubation with $\beta$-sitosterol oxides and $7 \beta$-hydroxycholesterol. DNA fragmentation was assessed by agarose gel electrophoresis. MW, molecularweight marker; 1, control; 2, $30 \mu \mathrm{M}-\beta$-sitosterol; 3, $60 \mu \mathrm{M}-\beta$-sitosterol; 4, $30 \mu \mathrm{M}$ - $\beta$-sitosterol oxides; $5,60 \mu \mathrm{M}-\beta$-sitosterol oxides; $6,120 \mu \mathrm{M}$ $\beta$-sitosterol oxides; 7, $30 \mu \mathrm{M}-7 \beta$-hydroxycholesterol; 8, $60 \mu \mathrm{M}$-sitosterol- $5 \alpha, 6 \alpha$-epoxide.

Effect of $\beta$-sitosterol, $\beta$-sitosterol oxides, $\alpha$-epoxysitosterol and $7 \beta$-hydroxycholesterol on DNA integrity

To assess the potential of $\beta$-sitosterol oxides to induce single-strand DNA breaks, U937 cells were incubated with the test compounds for $24 \mathrm{~h}$ and processed for the alkaline single-cell gel electrophoresis assay. None of the compounds significantly increased the formation of DNA single-strand breaks relative to the control. The average Olive tail moment of the comets was estimated for every sample. In contrast, upon exposure to increasing concentrations of $\mathrm{H}_{2} \mathrm{O}_{2}(25-500 \mu \mathrm{M})$, DNA damage in U937 cells was significant and dose-dependent (data not shown).

Effect of $\beta$-sitosterol, $\beta$-sitosterol oxides, $\alpha$-epoxysitosterol and $7 \beta$-hydroxycholesterol on sister chromatid exchange

The addition of any of the test compounds or solvents to the growth medium did not affect the background frequency of SCE. In control cells the SCE/chromosome was 0.26 (SEM 0.01) (results from three independent experiments). In contrast, treatment with $\mathrm{H}_{2} \mathrm{O}_{2}(50$ and $100 \mu \mathrm{M})$ significantly increased $(P<0 \cdot 01)$ the number of SCE in respect of the control samples. The SCE/chromosome increased to 0.67 (SEM 0.02) and 0.75 (SEM 0.02) (results from three independent experiments) following treatment with 50 and $100 \mu \mathrm{M}-\mathrm{H}_{2} \mathrm{O}_{2}$ respectively. The mitotic index was not affected by any of the treatments used in the present study. The replicative index of V79 cells was significantly decreased $(P<0.01)$ following treatment with $100 \mu \mathrm{M}-\mathrm{H}_{2} \mathrm{O}_{2}$. The replicative index/100 nuclei was 2.03 (SEM 0.02) \% in control cells and 1.15 (SEM 0.09) $\%$ in $100 \mu \mathrm{M}-\mathrm{H}_{2} \mathrm{O}_{2}$-treated cells. The genotoxin $\left(\mathrm{H}_{2} \mathrm{O}_{2}\right)$ was not cytotoxic at the concentration used in the experiments as measured by the neutral red uptake assay (data not shown).

\section{Discussion}

Our findings demonstrate that $\beta$-sitosterol oxides exhibit similar patterns of toxicity as the COP, $7 \beta-\mathrm{OH}$. The phytosterol oxides used in the present study contain a mixture of oxidation products as indicated by TLC (Fig. 2). In relation to COP, Aupeix et al. (1995) reported that simultaneous administration of equimolar concentrations of these compounds to U937 cells resulted in quenching effects on the COP-induced toxicity. Leonarduzzi et al. (2001) demonstrated that equimolar amounts of 7-ketocholesterol and a mixture of COP, representative of that found in oxidised LDL, were significantly more potent at inducing apoptosis in cultured macrophages when used alone compared with a mixture. Thus, mixtures of oxysterols (COP) may be less toxic towards vascular cells than single purified compounds. In this regard, it would be extremely interesting to extend the toxicological analysis to individual phytosterol oxides rather than mixtures of these compounds. However, individual phytosterol oxides are not commercially available.

There have been very few reports on the physiological effects of phytosterol oxides. Adcox et al. (2001) studied the cytotoxicity of cholesterol, a $\beta$-sitosterol-campesterol mixture $(50: 40 \%)$, and their oxides in a cultured-derived macrophage cell line. They reported that cholesterol oxides and $\beta$-sitosterol-campesterol oxides exhibit similar patterns of toxicity; however, the effects were less severe with the phytosterol oxides. In line with our findings, they also found the parent phytosterol to be non-toxic. Our results also indicate that the compound, $\alpha$-epoxysitosterol, was not toxic to U937 cells. It had no effect on cell viability or induction of apoptosis, nor was any DNA laddering evident. This is consistent with results reported by O'Callaghan et al. (2001) for the corresponding COP, cholesterol-5 $\alpha, 6 \alpha$-epoxide. Cholesterol- $5 \alpha, 6 \alpha$-epoxide was not toxic to, and did not induce apoptosis in, U937 cells. Analytical methods for measuring phytosterol oxides in foods and biological samples have improved in recent years (Dutta, 2002). Some recent developments in the area of separation of phytosterol oxides by high-resolution capillary column GLC are now allowing accurate identification and quantification of these compounds. Grandgirard (2002) reported on the presence of phytosterol oxides in plasma from healthy human subjects. The main compounds identified were $\beta$-epoxysitosterol and sitostanetriol. A trace of 7-ketositosterol was also observed. Plat et al. (2001) reported on the presence of phytosterol oxides in serum from phytosterolaemic patients. Similar oxidation products to those formed from cholesterol were identified. In fact, approximately $1.4 \%$ of the sitosterol molecules in these 
patients' serum was oxidised. This is considerably higher than the approximately $0.01 \%$ oxidatively modified cholesterol normally present in healthy human serum. One of the most atherogenic cholesterol oxides is $7 \beta-\mathrm{OH}$ and Plat et al. (2001) found both 7 $\beta$-hydroxysitosterol and $7 \beta$-hydroxycampesterol in serum from phytosterolaemic patients. They reported plasma $7 \beta$-hydroxysitosterol concentrations of about $2 \mu \mathrm{M}$ and slightly higher concentrations for 7-ketositosterol. Patients suffering from phytosterolaemia have a strong predisposition to premature coronary atherosclerosis (Bjorkhem \& Boberg, 1994). Increasing evidence suggests that cholesterol oxides are atherogenic and may play a role in plaque development in man. Most of the information on the toxicity of cholesterol oxides derives from in vitro studies where various cell types, including vascular cells, were exposed to high concentrations of these compounds (for a recent review, see Leonarduzzi et al. 2002). The levels of phytosterol oxides used in our studies are similar or lower than the levels of cholesterol oxides used in published in vitro models. These levels are higher than those encountered physiologically. Thus, the relevance of published findings on in vitro effects of cholesterol oxides and our findings on phytosterol oxides needs further investigation. Clearly, the biological effects of phytosterol oxides in man remain unknown. Given the structural similarities between cholesterol oxides and phytosterol oxides, model systems that have been used to study cholesterol oxides are suitable for analysis of phytosterol oxides.

An interesting report by Clare et al. (1995) found that addition of cholesterol in vitro to human monocytemacrophages protected against cell damage induced by 25- and 26-hydroxycholesterol but not 7-position cholesterol oxides. The possible protective role of cholesterol against phytosterol oxide toxicity in vitro merits further investigation.

It has been reported that glutathione depletion precedes and may be an early indicator of apoptotic cell death (Lizard et al. 1998). However, it may not be an obligatory pathway in oxysterol-mediated cytotoxicity (Therond et al. 2000). In the present study, the first manifestation of cytotoxicity with the high concentration of $\beta$-sitosterol oxides appears to be the reduction of cellular glutathione. This reduction was observed following $12 \mathrm{~h}$ incubation with $120 \mu \mathrm{M}-\beta$-sitosterol oxides and $30 \mu \mathrm{M}-7 \beta-\mathrm{OH}$. There was no reduction in cellular glutathione levels at the $12 \mathrm{~h}$ time point with $\beta$-sitosterol oxides at $60 \mu \mathrm{M}$, although after $24 \mathrm{~h}$ the percentage of apoptotic cells had increased to $35 \%$. This is consistent with the results of Ghibelli et al. (1998), where it was reported that a lag between glutathione extrusion and the onset of apoptosis in U937 cells exists but may be too short to be detected in oxidative stress-induced apoptosis. Catalase activity also plays an important role in protection against oxidative stress. Cantwell \& Devery (1998) reported that catalase activity is increased in rat hepatocytes exposed to COP. However, in the present study, catalase activity of U937 cells was unaltered after a $12 \mathrm{~h}$ incubation with $\beta$-sitosterol oxides (30 and $60 \mu \mathrm{M}$ ) and $30 \mu \mathrm{M}-7 \beta-\mathrm{OH}$. These findings are consistent with results in relation to COP reported by O'Callaghan et al. (2002).
$\beta$-Sitosterol oxides do not appear to be genotoxic to U937 cells as assessed using the DNA comet assay. The average Olive tail moment of comets obtained from $\beta$-sitosterol oxide-treated cells, which best characterises the degree of DNA damage, did not significantly alter in comparison with the control. In contrast, upon exposure to increasing concentrations of $\mathrm{H}_{2} \mathrm{O}_{2}(25-500 \mu \mathrm{M})$, DNA damage in U937 cells was significant $(P<0 \cdot 01)$, and dose-dependent. The SCE assay is a sensitive indicator of genotoxicity and involves the exchange of DNA between two homologous sister chromatids. $\mathrm{H}_{2} \mathrm{O}_{2}$ treatment resulted in a significant increase in SCE and decrease in the replicative index of the cells. However, none of the sterols and sterol oxides displayed genotoxic effects with regard to induction of SCE and effects on mitotic or replicative indices. Similarly, COP have previously been reported to be non-genotoxic to mammalian cells in culture (Woods \& O'Brien 1998).

In conclusion, the effects of phytosterol oxides on U937 cells closely resemble that of the $\mathrm{COP}, 7 \beta-\mathrm{OH}$, although higher concentrations of the former are required. COP are considered as potentially important factors in the development of human health disorders such as atherosclerosis (Leonarduzzi et al. 2002). Indeed, $7 \beta-\mathrm{OH}$ in plasma is considered to be a good marker of the risk for cardiovascular disease (Zieden et al. 1999). With the increasing ingestion of foods enriched in phytosterols, it is essential to investigate the biological activity of separate $\beta$-sitosterol oxides to establish the hierarchy of toxicity of these products, and similarity or difference of their action on cells as compared with their structurally similar and functionally analogous COP.

\section{References}

Adcox C, Boyd L, Oehrl L, Allen J \& Fenner G (2001) Comparative effects of phytosteroloxides and cholesterol oxides in cultured macrophage-derived cell lines. J Agric Food Chem 49, 2090-2095.

Aupeix K, Weltin D, Mejia JE, et al. (1995) Oxysterol-induced apoptosis in human monocytic cell lines. Immunobiology 194, 415-428.

Baudhuin P, Beaufay H, Rahman-Li Y, et al. (1964) Tissue fractionation studies. 17. Intracellular distribution of monoamine oxidase, aspartate aminotransferase, alanine aminotransferase, D-amino acid oxidase and catalase in rat-liver tissue. Biochem $J$ 92, 179-184.

Bjorkhem I \& Boberg KM (1994) Inborn errors in bile acid biosynthesis and storage of sterols other than cholesterol. In The Metabolic Basis of Inherited Diseases, pp. 2073-2100 [CR Scriver, AL Beaudet, WS Sly and D Valle, editors]. New York, NY: McGraw Hill.

Cantwell H \& Devery R (1998) The response of the antioxidant defense system in rat hepatocytes challenged with oxysterols is modified by Covi-ox. Cell Biol Toxicol 14, 401-409.

Christ M, Luu B, Mejia JE, Moosbrugger I \& Bischoff P (1993) Apoptosis induced by oxysterols in murine lymphoma cells and in normal thymocytes. Immunobiology 78, 455-460.

Clare K, Hardwick SJ, Carpenter KLH, Weeratunge N \& Mitchinson MJ (1995) Toxicity of oxysterols to human monocyte-macrophages. Atherosclerosis 118, 67-75.

Clifton P (2002) Plant sterols and stanols: comparisons and 
contrasts. Sterols versus stanols in cholesterol-lowering: is there a difference? Atheroscler Suppl 3, 5-9.

Daly GG, Finocchiaro ET \& Richardson T (1983) Characterization of some oxidation products of $\beta$-sitosterol. J Agric Food Chem 31, 46-50.

Dubrez L, Savoy I, Hamman A \& Solary E (1996) Pivotal role of a DEVD-sensitive step in etoposide-induced and Fas-mediated apoptotic pathways. EMBO J 15, 5504-5512.

Dutta PC (1999) Phytosterol oxides in some samples of pure phytosterols mixture and in a few tablet supplement preparations in Finland. In Natural Antioxidant and Anticarcinogens in Nutrition, Health and Disease, pp. 316-320 [JK Kumpulainen and JT Salonen, editors]. Cambridge, UK: The Royal Society of Chemistry.

Dutta PC (2002) Determination of phytosterol oxidation products in foods and biological samples. In Cholesterol and Phytosterol Oxidation Products, Analysis, Occurrence, and Biological Effects, pp. 335-374 [F Guardiola, PC Dutta, $\mathrm{R}$ Codony and GP Savage, editors]. Champaign, IL: AOCS Press.

Dutta PC \& Appelqvist LA (1997) Studies on phytosterol oxides. I: Effect of storage on the content in potato chips prepared in different vegetable oils. J Am Oil Chem Soc 74, 647-657.

Fieser M \& Fieser LF (1967) Reagents for Organic Synthesis, vol. 1, pp. 136, New York, NY: J. Wiley and Sons.

Ghibelli L, Coppola S, Fanelli C, et al. (1999) Glutathione depletion causes cytochrome c release even in the absence of cell commitment to apoptosis. FASEB J 13, 2031-2036.

Ghibelli L, Fanelli C, Rotilio G, et al. (1998) Rescue of cells from apoptosis by inhibition of active GSH extrusion. FASEB $J \mathbf{1 2}$ 479-486.

Grandgirard A (2002) Biological effects of phytosterol oxidation products, future research areas and concluding remarks. In Cholesterol and Phytosterol Oxidation Products, Analysis, Occurrence, and Biological Effects, pp. 375-382 [F Guardiola, PC Dutta, R Codony and GP Savage, editors]. Champaign, IL: AOCS Press.

Grandgirard A, Sergiel JP, Nour M, Demaison-Meloche J \& Ginies C (1999) Lymphatic absorption of phytosterol oxides in rats. Lipids 34, 563-570.

Hissin PJ \& Hilf R (1976) A fluorometric method for determination of oxidized and reduced glutathione in tissues. Anal Biochem 74, 214-226.

Kakis G, Kuksis A \& Myher JJ (1977) Injected 7-oxycholesterol and plant sterol derivatives and hepatic cholesterogenesis. $A d v$ Exp Med Biol 82, 297-299.

Lake RJ \& Scholes P (1997) Consumption of cholesterol oxides from fast foods fried in beef fat in New Zealand. $J$ Am Oil Chem Soc 74, 1069-1075.

Leonarduzzi G, Sevanian A, Sottero B, et al. (2001) Up-regulation of the fibrogenic cytokine TGF- $\beta 1$ by oxysterols: a mechanistic link between cholesterol and atherosclerosis. FASEB J 15, 1619-1621.

Leonarduzzi G, Sottero B \& Poli G (2002) Oxidised products of cholesterol: dietary and metabolic origin, and proatherosclerotic effects (review). J Nutr Biochem 13, 700-710.

Lizard G, Gueldry S, Sordet O, et al. (1998) Glutathione is implied in the control of 7-ketocholesterol-induced apoptosis, which is associated with radical oxygen species production. FASEB J 12, 1651-1663.

Lizard G, Monier S, Cordelet C, et al. (1999) Characterisation and comparison of the mode of cell death, apoptosis versus necrosis, induced by $7 \beta$-hydroxycholesterol and 7-ketocholesterol in the cells of the vascular wall. Arterioscler Thromb Vasc Biol 19, $1190-1200$
Lyons NM, Woods JA \& O'Brien NM (2001) $\alpha$-Tocopherol, but not $\gamma$-tocopherol inhibits $7 \beta$-hydroxycholesterol-induced apoptosis in human U937 Cells. Free Radic Res 35, 329-339.

Moreau RA, Whitaker BD \& Hicks KB (2002) Phytosterols, phytostanols, and their conjugates in foods: structural diversity, quantitative analysis, and health-promoting uses. Prog Lipid Res 41, 457-500.

Mowles JM (1990) Mycoplasma detection. In Methods in Molecular Biology, vol. V: Animal Cell Culture, pp. 65-74 [JW Pollard and JM Walker, editors]. Clifton, NJ: Humana Press.

O'Callaghan YC, Woods JA \& O'Brien NM (1999) Oxysterolinduced cell death in U937 and HepG2 cells at reduced and normal serum concentrations. Eur J Nutr 38, 255-262.

O'Callaghan YC, Woods JA \& O'Brien NM (2001) Comparative study of the cytotoxicity and apoptosis-inducing potential of commonly occurring oxysterols. Cell Biol Toxicol 17, $127-137$.

O'Callaghan YC, Woods JA \& O'Brien NM (2002) Characteristics of 7ß-hydroxycholesterol-induced cell death in a human monocytic blood cell line, U937, and a human hepatoma cell line, HepG2. Toxicol In Vitro 16, 245-251.

O'Leary KA, Woods JA \& O'Brien NM (2001) $\gamma$-Tocopherol is less effective than $\alpha$-tocopherol in preventing oxidant-induced sister chromatid exchanges in chinese hamster V79 cells. Free Radic Res 35, 917-924.

Olive PL \& Banath JP (1993) Induction and rejoining of radiation-induced DNA single-strand breaks: "tail moment" as a function of position in the cell cycle. Mutat Res 294, 275-283.

Perry P \& Wolff S (1974) New Giemsa method for the differential staining of sister chromatids. Nature 251, 156-158.

Plat J, Brzezinka H, Lutjohann D, Mensink RP \& von Bergmann K (2001) Oxidized plant sterols in human serum and lipid infusions as measured by combined gas-liquid chromatography-mass spectrometry. J Lipid Res 42, 2030-2038.

Smith PK, Krohn RI, Hermanson GT, et al. (1985) Measurement of protein using bicinchoninic acid. Anal Biochem 150, $76-85$.

Strauss GHS (1991) Non-random cell killing in cryopreservation: implications for performance of the battery of leukocyte tests (BLT), I. Toxic and immunotoxic effects. Mutat Res 252, $1-15$.

Tai CY, Chen YC \& Chen BH (1999) Analysis, formation and inhibition of cholesterol oxidation products in foods: an overview (Part I). J Food Drug Anal 7, 243-257.

Therond P, Abella A, Laurent D, et al. (2000) In vitro study of the cytotoxicity of isolated oxidized low-density lipoproteins fractions in human endothelial cells: Relationship with the glutathione status and cell morphology. Free Radic Biol Med 28, 585-596.

Van de Bovenkamp P, Kosmeijer-Schuil TG \& Katan MB (1988) Quantification of oxysterols in Dutch foods: egg products and mixed diets. Lipids 23, 1079-1085.

Woods JA \& O'Brien NM (1998) Investigation of the potential genotoxicity of cholesterol oxidation products in two mammalian fibroblast cell lines. Nutr Cancer 31, 192-198.

Woods JA, O'Leary KA, McCarthy RP \& O'Brien NM (1999) Preservation of comet assay slides: comparison with fresh slides. Mutat Res 429, 181-187.

Zieden A, Kaminskas A, Kristenson M, Kucinskiene Z, Vessby B, Olsson AG \& Piczfalusy U (1999) Increased plasma $7 \beta$-hydroxycholesterol concentrations in a population with a high risk for cardiovascular disease. Arterioscler Thromb Vasc Biol 19, 967-971. 